\title{
Cadmium Chloride Toxicity Revisited: Effect on Certain Andrological, Endocrinological and Biochemical Parameters of Adult Male Rabbits
}

\author{
S. SAJJAD ${ }^{1}$, H. MALIK ${ }^{1}$, U. FAROOQ ${ }^{2}$, F. RASHID ${ }^{1}$, H. NASIM ${ }^{1}$, S. TARIQ ${ }^{1}$, S. REHMAN ${ }^{1}$ \\ ${ }^{1}$ Department of Zoology, Lahore College for Women University, Lahore, Pakistan, ${ }^{2}$ University \\ College of Veterinary and Animal Sciences, The Islamia University of Bahawalpur, Pakistan
}

Received August 18, 2013

Accepted February 10, 2014

On-line April 3, 2014

\begin{abstract}
Summary
The present study was devised to assess the effects of cadmium chloride $\left(\mathrm{CdCl}_{2}\right)$ administration on certain andrological, endocrinological and biochemical alterations in adult male rabbits $(n=24)$. The animals were assigned to control $(n=8)$ and experimental $(n=16)$ group. Experimental group was orally administered with $1.5 \mathrm{mg} / \mathrm{kg}$ body weight of $\mathrm{CdCl}_{2}$. The trials were carried out for a total of 5 weeks and blood sampling was carried out on weekly basis. A gradual decrease was noticed for body weight in the experimental group from week 1 to 5 , being significantly lower in week 4 and $5(P<0.05)$. A similar decremented trend was noticed for serum testosterone level being significantly lower in experimental group in week 4 and 5 $(P<0.001)$. Significantly lower values were noticed for prolactin in experimental group in week 4 and $5(P<0.05)$, than in the control. On the contrary, serum cortisol level showed a gradual increase in experimental group, from week 1 to 5 , being significantly higher in week 4 and $5(P<0.05)$. Regarding the biochemical attributes, all the parameters under study revealed a gradually ascending trend. Statistical significance was, however, achieved in varying weeks and at varying levels. The total protein and albumin were significantly higher in week 4 and $5(P<0.01)$; alanine aminotransferase in week $2(P<0.01)$, $3(\mathrm{P}<0.001), \quad 4(\mathrm{P}<0.01) \quad$ and $\quad 5(\mathrm{P}<0.001) ;$ aspartate aminotransferase in week $1,2,3,4$ and $5(P<0.01)$; and alkaline phosphatase in week $1,2(P<0.01), 3,4$ and $5(P<0.0001)$, respectively. Overall mortality rate in experimental group was 68.75 (11/16). In a nutshell, Cd exposure results in adverse effects on all physiological parameters of body and may lead to lethal consequences.
\end{abstract}

\section{Key words}

Cadmium • Endocrine disruptors • Prolactin • Cortisol

\section{Corresponding author}

U. Farooq, University College of Veterinary and Animal Sciences, The Islamia University of Bahawalpur, Pakistan. E-mail: umer.farooq@iub.edu.pk

\section{Introduction}

An Endocrine Disruptor/Endocrine Disrupting Chemical (EDC) is an exogenous substance that causes adverse effects on health in intact organisms and their progeny, secondary to changes in endocrine function (European Environment Agency 1997). The possible threat posed by the EDCs to health in human beings and animals at an equal pace, has now globally been accepted through extensive in vitro and in vivo experimentation (Safe et al. 2000). In humans, their effects are on male and female reproduction, breast development and cancer, prostate cancer, neuroendocrinology, thyroid, metabolism and obesity, and cardiovascular endocrinology (Maffinni et al. 2006). However, in animals, feminization of males, and various degrees of male genital abnormalities from mild to severe hypospadias, unilateral or bilateral cryptorchidism, and poorly developed testes are common manifestations in dogs, horses, goats and other domestic animals (Lange et al. 2002a, Meyer et al. 2006).

Cadmium $(\mathrm{Cd})$ is one such naturally occurring toxic metal, a potential pollutant emanating from industrial and agricultural sources and an EDC (Jarup and Akesson 2009). It is a contaminant in most human 
foodstuffs because of its high rates of soil-to-plant transfer, rendering diet as a primary source of exposure (Satarug et al. 2005). The toxicity of $\mathrm{Cd}$ at various tissue levels such as kidneys, liver and testes has previously been elucidated (Meyer et al. 2006). However, a detailed account of its basis of toxicity is yet to be unearthed. In Pakistan during recent years, air pollution has emerged an alarming issue because of the presence of toxic traces in the air owing to rapid industrialization and transportation (Government of Pakistan 2006). The Cd level in various species of vegetables from Peshawar, Punjab, Pakistan have been reported to be $<0.008 \mathrm{ppm}$ (Hussain et al. 2009). Similarly, alarming levels of $0.62 \mathrm{mg} / 1$ and 27.7 $\mathrm{ng} / \mathrm{m}^{3}$ of $\mathrm{Cd}$ have been reported for waste water and Airborne Particulate Matter, respectively in Pakistan (GOP 2006, Khan et al. 2009). However, an elaborative detail regarding $\mathrm{Cd}$ as environmental toxicant from Pakistan is still lacking. The present study was, therefore, designed with an objective to investigate the toxicity of cadmium chloride $\left(\mathrm{CdCl}_{2}\right)$ in terms of certain andrological, endocrinological and serum biochemical markers in adult male rabbits.

\section{Material and Methods}

\section{Study animals and management}

A total of 42 adult male rabbits (Oryctolagus cuniculus) ranging in age from 10 to 12 months of age, used for the toxicity tests, were purchased from the local market of Lahore, Pakistan. They were acclimatized to their housing and feeding regimen. Proper diet consisting of green fodder given thrice a day; vegetables fruits and dry feed (grains, i.e. wheat, corn and oat) twice a week and free access to water ad libitum was maintained.

\section{Determination of lethal doze $\left(L D_{50}\right)$}

For the determination of $\mathrm{LD}_{50}$ for $\mathrm{CdCl}_{2}$, 18 adult male rabbits were kept under the appropriate conditions of ventilation and feeding for 15 days. They were divided into 3 groups with 6 animals in each. Three different dozes of $\mathrm{CdCl}_{2}$, i.e. $1,1.5$ and $2 \mathrm{mg} / \mathrm{kg}$ were given to these groups, respectively through the oral administration. The dose-dependent effects in terms of body weight, physical evaluation and mortality were observed daily (Ghosh and Bhattacharya 1992). Ultimately, $1.5 \mathrm{mg} / \mathrm{kg}$ of $\mathrm{CdCl}_{2}$ was found to be the $\mathrm{LD}_{50}$.

\section{Toxicity trials}

A total of 24 rabbits were divided into 2 groups, i.e. control and experimental with 8 and 16 animals per group, respectively. The dosage administration was carried out on the daily basis. All animals in the experimental group were orally administered with $1.5 \mathrm{mg} / \mathrm{kg}$ body weight of $\mathrm{CdCl}_{2}$ dissolved in equivalent amount of saline $(0.9 \% \mathrm{NaCl}$, Otsuka Pakistan Ltd., F/4-9, H.I.T.E, Hub, Balochistan, Pakistan), whereas the control group was given $0.9 \%$ normal saline only. The trials were carried out for a total of 5 weeks.

\section{Blood/serum collection and analyses}

Blood samples $(4 \mathrm{ml})$ were collected aseptically from the marginal ear vein of each animal, on a weekly basis, under proper restraining protocol. It was transferred into vaccutainers containing thixotropic gel separator for serum separation. Serum was harvested and analyzed for testosterone, prolactin (PRL) and cortisol through MiniVIDAS 12 Compact Automated Immunoanalyzer. The biochemical attributes viz. total protein (TP), albumin, globulin, alanine aminotransferase (ALT), aspartate aminotransferase (AST) and alkaline phosphatase (ALP) were determined through semiautomatic chemistry analyzer (Chem 7, Germany). Detail of commercial kits used in the study is given in Table 1 .

\section{Statistical analysis}

Statistical analysis was conducted with the Statistical Package for Social Science (SPSS for Windows version 12, SPSS Inc., Chicago, IL, USA). Results were expressed as mean \pm SE. Group differences were tested for statistical significance by using repeated measures analysis of variance, followed by Bonferroni post-hoc test.

\section{Results}

\section{Andrological parameters}

The comparative mean $( \pm \mathrm{SE})$ values for andrological parameters viz. body weight and serum testosterone level in control and experimental group of adult male rabbits are presented in Table 2. A gradual decrease was noticed for body weight in the experimental group from week 1 to 5 , being significantly lower in week 4 and $5(\mathrm{P}<0.05)$. A similar decremented trend was noticed for testosterone level across the study weeks being significantly lower in experimental group in week 4 and $5(\mathrm{P}<0.001)$. 
Table 1. Detail of commercial kits used for assessment of various biochemical analyses of the study.

\begin{tabular}{|c|c|c|c|c|c|}
\hline \multirow[b]{2}{*}{ Attribute } & \multirow[b]{2}{*}{ Make and batch No. } & \multirow{2}{*}{$\begin{array}{l}\text { Minimum } \\
\text { detection } \\
\text { limit }\end{array}$} & \multicolumn{2}{|c|}{ Precision \% } & \multirow{2}{*}{ Sensitivity } \\
\hline & & & $\begin{array}{l}\text { Within } \\
\text { assay }\end{array}$ & $\begin{array}{c}\text { Between } \\
\text { assay }\end{array}$ & \\
\hline Testosterone & $\begin{array}{l}\text { AccuBind Testosterone ELISA Kit } \\
(3725-300 A) \text {, Monobind Inc. Lake } \\
\text { Forest, CA 92630, USA }\end{array}$ & $0.1 \mathrm{ng} / \mathrm{ml}$ & $4.5-7.3$ & $6.0-6.3$ & $0.38 \mathrm{pg} / \mathrm{ml}-0.038 \mathrm{ng} / \mathrm{ml}$ \\
\hline Prolactin & $\begin{array}{l}\text { AccuBind Active PRL ELISA Kit } \\
\text { (725-300A), Monobind Inc. Lake } \\
\text { Forest, CA 92630, USA }\end{array}$ & $5 \mathrm{ng} / \mathrm{ml}$ & $2.5-3.5$ & $3.5-4.7$ & $0.05 \mathrm{ng} / \mathrm{ml}-1 \mathrm{ng} / \mathrm{ml}$ \\
\hline Cortisol & $\begin{array}{l}\text { AccuBind Active Cortisol ELISA } \\
\text { Kit (3625-300A), Monobind Inc. } \\
\text { Lake Forest, CA 92630, USA }\end{array}$ & $0.1 \mu \mathrm{g} / \mathrm{dl}$ & $6.1-8.2$ & $7.3-9.7$ & $6.25 \mathrm{pg}-0.25 \mu / \mathrm{dl}$ \\
\hline Total protein & 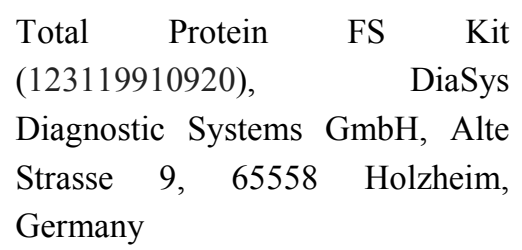 & $0.05 \mathrm{~g} / \mathrm{dl}$ & $1.14-1.25$ & $0.86-2.39$ & $0.05 \mathrm{~g} / \mathrm{dl}-15 \mathrm{~g} / \mathrm{dl}$ \\
\hline Albumin & $\begin{array}{l}\text { Albumin Kit (IUS-7-5UK), Chema } \\
\text { Diagnostica, Via Campania 2/4, } \\
60030 \text { Monsano (AN), Italy-EU }\end{array}$ & $0.2 \mathrm{~g} / \mathrm{dl}$ & $0.3-0.42$ & $0.7-1.14$ & $0.2 \mathrm{~g} / \mathrm{dl}-6 \mathrm{~g} / \mathrm{dl}$ \\
\hline $\begin{array}{l}\text { Alanine } \\
\text { aminotransferase }\end{array}$ & $\begin{array}{lcr}\text { ALAT Kit } \quad(127019910962) \\
\text { DiaSys } \quad \text { Diagnostic } & \text { Systems } \\
\text { GmbH, Alte Strasse } & 9, \quad 65558 \\
\text { Holzheim, Germany }\end{array}$ & $4 \mathrm{U} / 1$ & $1-6.22$ & $0.92-3.08$ & - \\
\hline $\begin{array}{l}\text { Aspartate } \\
\text { aminotransferase }\end{array}$ & \begin{tabular}{lcr} 
ASAT & Kit & \multicolumn{1}{c}{$(126019910021)$} \\
DiaSys & Diagnostic & Systems \\
GmbH, Alte Strasse & $9, \quad 65558$ \\
Holzheim, Germany &
\end{tabular} & $3 \mathrm{U} / 1$ & $1.40-2.02$ & $1.34-2.29$ & \\
\hline $\begin{array}{l}\text { Alkaline } \\
\text { phosphatase }\end{array}$ & $\begin{array}{l}\text { ALP Kit (104419910021), DiaSys } \\
\text { Diagnostic Systems GmbH, Alte } \\
\text { Strasse 9, } 65558 \text { Holzheim, } \\
\text { Germany }\end{array}$ & $3 \mathrm{U} / 1$ & $1.06-1.50$ & $0.85-1.60$ & \\
\hline
\end{tabular}

Table 2. Values for andrological parameters in control and cadmium chloride treated groups.

\begin{tabular}{llllllll}
\hline \multirow{2}{*}{ Parameters } & Groups & \multicolumn{7}{c}{ Weeks } & Overall \\
\cline { 3 - 6 } & & Week 1 & Week 2 & Week 3 & Week 4 & Week 5 \\
\hline \multirow{2}{*}{ Body weight $(\mathrm{kg})$} & Control & $1.2 \pm 0.1$ & $1.1 \pm 0.1$ & $1.1 \pm 0.1$ & $1.3 \pm 0.1$ & $1.1 \pm 0.05$ & $1.2 \pm 0.02$ \\
& Experimental & $1.4 \pm 0.2$ & $1.2 \pm 0.1$ & $1.03 \pm 0.09$ & $0.9 \pm 0.1 *$ & $0.9 \pm 0.03^{*}$ & $1.1 \pm 0.08$ \\
Testosterone $(\mathrm{ng} / \mathrm{ml})$ & Control & $3.9 \pm 0.3$ & $3.7 \pm 0.3$ & $3.7 \pm 0.2$ & $3.6 \pm 0.2$ & $3.8 \pm 0.3$ & $3.8 \pm 0.05$ \\
& Experimental & $3.9 \pm 0.2$ & $3.2 \pm 0.2$ & $2.5 \pm 0.4$ & $1.04 \pm 0.3 * *$ & $1.1 \pm 0.4^{* *}$ & $2.3 \pm 0.5$ \\
\hline
\end{tabular}

Values are presented as means $( \pm \mathrm{SE}) . * \mathrm{P}<0.05 ; * * \mathrm{P}<0.001$ 
Table 3. Values for endocrinological parameters in control and cadmium chloride treated groups.

\begin{tabular}{llllllll}
\hline \multirow{2}{*}{ Parameters } & \multirow{2}{*}{ Groups } & \multicolumn{7}{c}{ Weeks } & \\
\cline { 3 - 7 } & & Week 1 & Week 2 & Week 3 & Week 4 & Week 5 & Overall \\
\hline \multirow{3}{*}{ Prolactin $(\mathrm{ng} / \mathrm{ml})$} & Control & $0.5 \pm 0.02$ & $0.5 \pm 0.01$ & $0.5 \pm 0.02$ & $0.5 \pm 0.01$ & $0.6 \pm 0.02$ & $0.5 \pm 0.01$ \\
& Experimental & $0.5 \pm 0.01$ & $0.5 \pm 0.01$ & $0.5 \pm 0.01$ & $0.4 \pm 0.01^{*}$ & $0.4 \pm 0.01^{*}$ & $0.4 \pm 0.01$ \\
Cortisol $(\mu \mathrm{g} / \mathrm{dl})$ & Control & $3.4 \pm 0.1$ & $3.7 \pm 0.3$ & $4.01 \pm 0.1$ & $4.6 \pm 0.19$ & $4.7 \pm 0.3$ & $4.1 \pm 0.2$ \\
& Experimental & $3.6 \pm 0.05$ & $4.1 \pm 0.1$ & $4.4 \pm 0.07$ & $4.8 \pm 0.09^{*}$ & $5.6 \pm 0.1^{*}$ & $4.5 \pm 0.3$ \\
\hline
\end{tabular}

Values are presented as means $( \pm \mathrm{SE}) .{ }^{*} \mathrm{P}<0.05$

Table 4. Values for biochemical parameters in control and cadmium chloride treated groups.

\begin{tabular}{llllllll}
\hline \multirow{2}{*}{ Parameters } & Groups & \multicolumn{7}{c}{ Weeks } & Overall \\
\cline { 3 - 7 } & & Week 1 & Week 2 & Week 3 & Week 4 & Week 5 \\
\hline \multirow{2}{*}{ Total protein $(g / l)$} & Control & $4.7 \pm 0.3$ & $5.0 \pm 0.2$ & $4.9 \pm 0.3$ & $5.3 \pm 0.1$ & $5.3 \pm 0.2$ & $5.1 \pm 0.1$ \\
& Experimental & $5.1 \pm 0.2$ & $5.2 \pm 0.2$ & $5.2 \pm 0.1$ & $5.8 \pm 0.1^{*}$ & $5.8 \pm 0.1^{*}$ & $5.4 \pm 0.1$ \\
Albumin $(g / l)$ & Control & $3.1 \pm 0.1$ & $3.3 \pm 0.1$ & $3.2 \pm 0.7$ & $3.1 \pm 0.1$ & $3.4 \pm 0.12$ & $3.2 \pm 0.05$ \\
Alanine & Experimental & $3.6 \pm 0.1$ & $3.7 \pm 0.09$ & $3.8 \pm 0.06$ & $3.9 \pm 0.08^{*}$ & $3.9 \pm 0.07^{*}$ & $3.8 \pm 0.06$ \\
Aminotransferase (U/l) & Experimental & $41.0 \pm 18.1$ & $42.4 \pm 4.4^{*}$ & $46.7 \pm 4.6^{* *}$ & $55.1 \pm 6.2^{*}$ & $61.8 \pm 6.1^{* *}$ & $49.4 \pm 3.9$ \\
Aspartate & Control & $32.2 \pm 0.03$ & $33.5 \pm 0.1$ & $33.0 \pm 0.6$ & $35.5 \pm 0.04$ & $38.6 \pm 0.03$ & $34.6 \pm 1.1$ \\
Aminotransferase (U/l) & Experimental & $62.9 \pm 6.9^{*}$ & $65.0 \pm 7.0^{*}$ & $65.6 \pm 6.9^{*}$ & $71.5 \pm 7.7^{*}$ & $78.0 \pm 11.0^{*}$ & $68.6 \pm 2.7$ \\
Alkaline Phosphatase & Control & $19.4 \pm 0.7$ & $19.6 \pm 0.7$ & $19.9 \pm 0.7$ & $20.2 \pm 1.1$ & $20.6 \pm 1.1$ & $20.0 \pm 0.2$ \\
(U/l) & Experimental & $55.7 \pm 7.5^{*}$ & $55.5 \pm 7.7^{*}$ & $61.6 \pm 7.9^{* *}$ & $71.4 \pm 5.7^{* *}$ & $74.7 \pm 6.7^{* *}$ & $63.8 \pm 3.99$ \\
\hline
\end{tabular}

Values are presented as means $( \pm \mathrm{SE}) . * \mathrm{P}<0.01 ; * * \mathrm{P}<0.001$

\section{Endocrinological parameters}

The comparative mean $( \pm \mathrm{SE})$ values for endocrinological parameters viz. prolactin (PRL) and serum cortisol level in control and experimental group of adult male rabbits are presented in Table 3. Prolactin was found be in a close range for both groups under study during the study weeks. However, a significantly lower value was noticed in experimental group in week 4 and 5 $(\mathrm{P}<0.05)$, than in the control. On the contrary, serum cortisol level showed a gradual increase in experimental group, from week 1 to 5 , being significantly higher in week 4 and $5(\mathrm{P}<0.05)$.

\section{Biochemical parameters}

The comparative mean $( \pm \mathrm{SE})$ values for biochemical parameters in control and experimental groups of adult male rabbits are presented in Table 4. It was noted that all the parameters were altered in $\mathrm{Cd}$-administered group during the study weeks revealing a gradually ascending trend. Statistical significance was, however, achieved in varying weeks and at varying level. The TP and albumin were significantly higher in week 4 and $5(\mathrm{P}<0.01)$; ALT in week $2(\mathrm{P}<0.01), 3(\mathrm{P}<0.001)$, $4(\mathrm{P}<0.01)$ and $5(\mathrm{P}<0.001)$; AST in week $1,2,3,4$ and 5 $(\mathrm{P}<0.01)$; and ALP in week 1, $2(\mathrm{P}<0.01), 3,4$ and 5 $(\mathrm{P}<0.0001)$, respectively.

\section{Mortality}

There was no mortality in case of control animals $(n=8)$ as they survived throughout the study. However, the experimental animals started showing mortality from week 3 onwards with 4, 5 and 2 rabbits in week 3,4 and 5, respectively. An overall mortality rate of $68.75(11 / 16)$ was noticed in the study.

\section{Discussion}

$\mathrm{Cd}$ is ubiquitous environmental occupational 
pollutant which is adding up to our environment at a fast pace owing to both the natural and man-made activities. This might be more alarming for the flora and fauna of developing countries. Its true basis of toxicity yet needs to be unearthed. However, its direct action in free ionic form, and indirect action through hampering the oxidative-antioxidant balance of the body have been proposed through earlier studies (Stoths et al. 2001, Kowalczyk et al. 2003). The present study was devised to assess the effect of $\mathrm{CdCl}_{2}$ toxicity on certain andrological, endocrinological and biochemical parameters of adult male rabbits.

\section{Andrological parameters}

Our study revealed that $\mathrm{CdCl}_{2}$ administration decreased the body weight in the rabbits in week 4 and 5 of the trial. Previous studies (Zeng et al. 2003, Amara et al. 2008) have also revealed a reduction in body weight after a loss in appetite, as a primary manifestation of $\mathrm{CdCl} 2$ administration in rats. This decrease in body weight in post-pubertal Cd-treated animals might be correlated to the greater accumulation of $\mathrm{Cd}$ both in hypothalamus and pituitary glands of these animals. It is worth mentioning here that earlier studies on assessment of growth hormone $(\mathrm{GH})$ levels in Cd-administered rabbits have revealed that this decrease in body weight is not caused by alterations in the GH levels (Lafuente and Esquifino 2000). Contrary to our work, Jabeen and Chaudhry (2011) reported a non-significant effect of $\mathrm{Cd}$ administration on body weight of Sprague-Dawley rats. Difference in species under study and variation in dose rate could be plausible justifications for this variation.

It has been identified in various species of animals that $\mathrm{Cd}$ can act as an EDC exerting androgenic as well as estrogenic effects (Ronchetti et al. 2013). Testes in males have been considered as one of the major targets of $\mathrm{Cd}$ in many species of animals such as rats, rabbits and dogs (Biswas et al. 2001, Amara et al. 2008). Serum testosterone levels in the present study were decreased in $\mathrm{CdCl}_{2}$ administered group. Similar results have been reported by various workers on different species of animals; however, its mechanism of this effect has not yet been elucidated. Lafuente et al. (2000) reported increased $\mathrm{Cd}$ accumulation in the hypothalamus, pituitary, and testis and decreased plasma levels of follicle stimulating hormone in rats, suggesting a possible effect of $\mathrm{Cd}$ on the hypothalamic-pituitary-testicular axis. Others have quoted the Cd-induced oxidative stress in the testicular tissue as a prime cause for hampered steroidogenesis
(Valko et al. 2005). Cd-induced toxicity to the testis is probably the result of inter-digitating complex interactions which involve the disruption of the bloodtestis barrier via specific signal transduction pathways and signaling molecules (Siu et al. 2009).

\section{Endocrinological parameters}

The endocrinological parameters studied for the affect of $\mathrm{Cd}$ administration in the present study were serum PRL and cortisol levels. A gradual decrease was noticed in serum PRL level in Cd-induced experimental group, whereas a gradual increase was seen for serum cortisol. Our results are consistent with previous study in rats which demonstrated that cadmium accumulation differentially altered PRL and adrenocorticotropic hormone $(\mathrm{ACTH})$ episodic pattern of secretion in males (Lafuente et al. 2003). The serum PRL levels are under the dopaminergic system of the body. Cd has been shown to interfere with the genesis of biogenic amines from hypothalamus in rats, and hence inhibiting the PRL secretion (Lafuente et al. 2003). In a novel study on renal and neurogenic effects of various toxic metals in children, Burbure et al. (2006) reported a negative correlation of Cd with serum PRL levels.

Regarding serum cortisol level as affected by $\mathrm{Cd}$ exposure, various studies (Chowhdury et al. 2004, Wu et al. 2007) have indicated that the primary response to Cd-induced stress is an indication of the elevation of serum cortisol level. The general adaptation response of the animal to stressors is the increase of cortisol secretion. It has been reported that animals living in contaminated environments for longer duration experiences periods of high metabolic activity that could eventually lead to impaired cortisol secretion and cellular alterations. The direct toxic effect of $\mathrm{Cd}$ on adrenal tissue causes an elevated ACTH and hence, an increased serum cortisol level (Yin et al. 2000). However, the results of our study are not in line with studies conducted on fish which have reported the absence of Cd-induced cortisol response in fish (Dang et al. 2001, Lange et al. 2002b). The cortisol response might be more of a general phenomenon during exposure to various combinations to environmental stressors rather than a Cd-related specific effect (Lange et al. 2002b).

\section{Biochemical parameters}

For $\mathrm{Cd}$, the first organ reached after entry into the blood is liver where it causes direct effects of consecutive necrosis and apoptosis of hepatocytes and 
indirect effect of carcinogenesis (Zalups and Ahmad 2003). Biochemical parameters assessed in the present study revealed pronounced elevation at a gradual level in the weeks of study in Cd-administered group.

Assessment of TP is one of the vital diagnostic tools for hepatic injury. A gradual increase in its level in Cd-treated group in the present study is in line with previous work reported for various animal species (Zalups and Ahmad 2003, Sant'Ana et al. 2005). The increasing trend in protein concentration with exposure duration might be the result of $\mathrm{Cd}$ interrupting with cellular mechanisms as it accumulates in liver and conjugates with metallothionine (Godt et al. 2006). Contrary to our results, Abou El-Naga et al. (2005) reported no effect of $\mathrm{Cd}$ administration on $\mathrm{TP}$ concentration of marine fish. Further comparative research is needed on different animal models to assess these variations.

The albumin level also showed a gradual increase in Cd-treated groups in the present study. The results are not in line with those published earlier which have reported a significant hypoalbuminema in Cd-administered rabbits (Hristev et al. 2007, Hassan et al. 2012). This decrease was attributed to the focal hemorrhages in liver parenchyma which ultimately resulted in decreased albumin genesis from hepatocytes. These variations could be because of varying experimental procedures in terms of dosage and time of trials conducted.

The concentration of liver enzymes in blood provides a reliable diagnostic approach to the degree of hepatic injury and status of hepatic physiology. The three enzymes studied here, i.e. ALT, AST and ALP revealed an ascending trend in Cd-administered rabbits during the study period. Interestingly, significant difference for these enzymes was evident from the very first week of study. Similar results have been reported earlier (Hristev et al. 2007, Hassan et al. 2012). Accumulative affinity of
$\mathrm{Cd}$ for liver causing focal hemorrhages and lipid peroxidation of its parenchyma has been given as plausible justification for this increase in hepatic enzymes (Godt et al. 2006). An early onset of difference in the liver enzyme levels between control and experimental group in the present study is in line with previous work (Hassan et al. 2012). This is a clear indication of liver being the primary site of accumulation for $\mathrm{Cd}$ and a major target organ.

\section{Mortality}

In the present study, no mortality was seen in rabbits of control group. However, it started in Cdadministered group from week 3 onwards with an overall rate of 68.75. A lower mortality rate of 39.4 has been reported for $\mathrm{CdCl}_{2}$ treated rabbits (Hassan et al. 2012). Variation in these results could be because of different in dosage rate of $\mathrm{CdCl}_{2}$ or breed. The mortality is not a direct effect of cadmium as such. It is rather attributed to its nephropathic/nephrotoxic ability which causes kidney failure and hence death (Godt et al. 2006).

In a nutshell, $\mathrm{Cd}$ exposure results in adverse effects on all physiological parameters of body and may lead to lethal consequences. Developing countries, in specific, need to devise directional protocols for monitoring the factors which could be responsible for $\mathrm{Cd}$ addition in environment. Furthermore, surveillance needs to be carried out, in order to assess the $\mathrm{Cd}$ exposure both at human and animal level.

\section{Conflict of Interest}

There is no conflict of interest.

\section{Acknowledgements}

The research was funded by the Lahore College of Women University's Internal Research Fund for which the authors are grateful.

\section{References}

ABOU EL-NAGA EH, KHALID ME, MOHAMED AH: Toxicity of cadmium and copper and their effect on some biochemical parameters of marine fish. Egypt J Aquat Res 31: 60-71, 2005.

AMARA S, ABDELMELEK H, GARREL C, GUIRAUD P, DOUKI T, RAVANAT J, FAVIER A, SAKLY M, BEN RHOUMA K: Preventive effect of zinc against cadmium-induced oxidative stress in rat testis. $J$ Reprod Dev 54: 129-134, 2008.

BISWAS NM, SENGUPTA R, CHATOPADHYAY GR, CHOUDHURY A, SARKAR M: Effect of ethanol on cadmium-induced testicular toxicity in male rats. Reprod Toxicol 15: 699-704, 2001. 
BURBURE C, BUCHET J, LEROYER A, NISSE C, HAGUENOER J, MUTTI A, SMERHOVSKY Z, CIKRT M, MALGORZATA T, RAZNEIWSKA G, JAKUBOWSKI M, BERNARD A: Renal and neurologic effects of cadmium, lead, mercury, and arsenic in children: evidence of early effects and multiple interactions at environmental exposure levels. Environ Health Persp 114: 584-590, 2006.

CHOWHDURY MJ, MCDONALD DG, WOOD CM: Gastrointestinal uptake and fate of cadmium in rainbow trout acclimated to sublethal dietary cadmium. Aquat Toxicol 69: 149-163, 2004.

DANG ZC, BERNTSSEN MHG, LUNDEBYE AK, FILK G, BONGA SEW, LOCK RAC: Metallothionein and cortisol receptor expression in gills of Atlantic salmon, Salmo salar, exposed to dietary cadmium. Aquat Toxicol 63: 91-101, 2001.

EUROPEAN ENVIRONMENT AGENCY: European workshop on the impact of endocrine disruptors on human health and wildlife, 2-4 December 1996, Weybridge, UK. Report of the Proceedings. Report EU 17549. Copenhagen: European Commission DG VII.

GHOSH N, BHATTACHARYA S: Thyrotoxicity of the chlorides of cadmium and mercury in rabbit. Bio Med Environ Sci 5: 236-240, 1992.

GODT J, SCHEIDIG F, SIESTRUP CG, ESCHE V, BRANDENBERG P, REICH A, GRONEBERG DA: The toxicity of cadmium and insulting hazards for the human health. J Occ Toxicol 1: 22-26, 2006.

GOVERNMENT OF PAKISTAN: Report on assessment of lead and cadmium in Pakistan. Ministry of Environment, Pakistan, 2006.

HASSAN RA, AMIN DM, RAHMY NA, HATEM ME, DESSOUKY MI: Clinicopathological, histopathological and immunological studies on animals exposed to lead and cadmium under experimental conditions. New York Sci J 5: 120-136, 2012.

HRISTEV H, PENKOV D, HALLAK AK, KIROVA M, BAYKOV B, BIZNAKOV A: Serum protein changes in rabbits after chronic administration of lead and cadmium. J Central Euro Agric 9: 157-162, 2007.

HUSSAIN J, KHAN AL, REHMAN N, HAMAYUN N, SHAH T, NISAR M, BANO T, SHINWARI ZK, LEE I: Proximate and nutrient analysis of selected vegetable species: a case study of Karak region, Pakistan. Afr $J$ Biotech 8: 2725-2729, 2009.

JARUP L, AKESSON A: Current status of cadmium as an environmental health problem. Toxicol Appl Pharmacol 238: 201-208, 2009.

JABEEN F, CHAUDHRY AS: Effects of sodium selenite in cadmium chloride induced hepatoxicity in male SpragueDawley rats. Pak J Zool 43: 957-965, 2011.

KHAN S, AHMAD I, SHAH MT, REHMAN S, KHALIQ A: Use of constructed wetland for the removal of heavy metals from industrial wastewater. J Environ Manage 90: 3451-3457, 2009.

KOWALCZYK E, KOPFF A, FIJALKOWSKI P, KOPFF M, NIEDWOROK J, BLASZCYZK J, KEDZIORA J, TYSLEROWICZ P: Effect of anthocyanins on selected biochemical parameters in rats exposed to cadmium. Acta Biochim Pol 50: 543-548, 2003.

LAFUENTE A, ESQUIFINO AI: Cadmium effects on hypothalamic activity and pituitary hormone secretion in the male. Toxicol Lett 110: 209-218, 2000.

LAFUENTE A, MARQUEZ N, PEREZ-LORENZO M, PAZO D, ESQUIFINO AI: Pubertal and postpubertal cadmium exposure differentially affects the hypothalamic-pituitary-testicular axis function in the rat. Food Chem Toxicol 38: 913-923, 2000.

LAFUENTE A, CANO P, ESQUIFINO A: Are cadmium effects on plasma gonadotropins, prolactin, ACTH, GH and TSH levels, dose-dependent? Biometals 16: 243-250, 2003.

LANGE IG, DAXENBERGER A, SCHIFFER B, WITTERS H, IBARRETA D, MEYER HHD: Sex hormones originating from different livestock production systems: fate and potential disrupting activity in the environment. Anal Chim Acta 473: 27-37, 2002a.

LANGE A, AUSSEIL O, SEGNER H: Alterations of tissue glutathione levels and metallothionein mRNA in rainbow trout during single and combined exposure to cadmium and zinc. Comp Biochem Phys C 131: 231-243, $2002 \mathrm{~b}$.

MAFFINNI MV, RUBIN BS, SONNENSCHEIN C, SOTO AM: Endocrine disruptors and reproductive health: the case of bisphenol-A. Mol Cell Endocrinol 254-255: 179-186, 2006. 
MEYER KJ, REIF JS, VEERAMACHANENI DNR, LUBEN TJ, MOSLEY BS, NUCKOLS JR: Agricultural pesticide use and hypospadias in eastern Arkansas. Environ Health Persp 114: 1589-1595, 2006.

RONCHETTI SA, MILER EA, DUVILANSKI BH, CABILLA JP: Cadmium mimics estrogen-driven cell proliferation and prolactin secretion from anterior pituitary cells. Plos One 8: 1-13, 2013.

SAFE SH, FOSTER WG, LAMB JC, NEWBOLD RR, VAN DER KRAAK G: Estrogenicity and endocrine disruption. Report No.: 16. Iowa: Council for Agricultural Science and Technology, 2000.

SANT'ANA MG, MORAES R, BERNARDI MM: Toxicity of cadmium in Japanese quail: evaluation of body weight, renal function and cellular immune response. Environ Res 99: 273-277, 2005.

SATARUG S, NISHIJO M, UJJIN P, VANAVANITKUN Y, MOORE MR: Cadmium-induced nephropathy in the development of high blood pressure. Toxicol Lett 157: 57-68, 2005.

SIU ER, MRUK DD, PORTO CS, CHANG CY: Cadmium-induced testicular injury. Toxicol Appl Pharm 28: 240-249, 2009.

STOTHS SJ, BAGCHI D, HASSOUN E, BAGCHI M: Oxidative mechanisms in the toxicity of chromium and cadmium ions. J Environ Pathol Toxicol Oncol 20: 77-82, 2001.

VALKO M, MORRIS H, CRONIN MTD: Metals, toxicity and oxidative stress. Curr Med Chem 12: 1161-1208, 2005.

WU SM, SHIH MJ, HO YC: Toxicological stress response and cadmium distribution in hybrid tilapia (Oreochromis sp.) upon cadmium exposure. Comp Biochem Physiol C 145: 218-226, 2007.

YIN S, SHEU J, LIN T: Lipid peroxidation in rat adrenal glands after administration cadmium and role of essential metals. J Toxicol Env Heal A 62: 47-56, 2000.

ZALUPS RK, AHMAD S: Molecular handling of cadmium in transporting epithelia. Toxicol Appl Pharmacol 186: 163-188, 2003.

ZENG X, JIN T, ZHOU Y, NORDBERG GF: Changes of serum sex hormone levels and MT mRNA expression in rats orally exposed to cadmium. J Toxicol 186: 109-118, 2003. 